\title{
БРЕНД-МЕНЕДЖМЕНТ У СИСТЕМІ СТРАТЕГІЧНОГО УПРАВЛІННЯ ПІДПРИЄМСТВОМ
}

\section{BRAND MANAGEMENT IN THE STRATEGIC ENTERPRISE MANAGEMENT SYSTEM}

\section{УДК 336.71}

https://doi.org/10.32843/infrastruct38-30

\author{
Мартич Є.C. \\ студентка \\ Харківський навчально-науковий \\ інститут \\ ДВНЗ «Університет банківської справи» \\ Христофорова О.М. \\ к.е.н., доцент кафредри менеджменту \\ та соціально-гуманітарних дисциплін \\ Харківський навчально-науковий \\ інститут \\ ДВНЗ «Університет банківської справи» \\ Новікова Т.В. \\ к.е.н., доцент кафедри менеджменту \\ та соціально-гуманітарних дисциплін \\ Харківський навчально-науковий \\ інститут \\ ДВНЗ «Університет банківської справи»
}

\begin{abstract}
Створення та управління брендами є запорукою отримання конкурентних переваг та довгострокової рентабельності продуктів, послуг, компаній та організацій. Глибинні та науково обґрунтовані знання з питань маркетингу, інновацій та управління брендами є важливими для кожного бізнесу та організації. Розуміння поведінки споживача $\epsilon$ основою для розроблення стратегій брендменеджменту, а також оптимального позиціонування на ринку та ефективноі маркетингової тактики. у статті розглядаються проблеми визначення завдань бренд-менеджменту у контексті стратегічного розвитку підприємства. Показано, що використання бренд-менеджменту $\epsilon$ проявом інноваційної активності та стратегічного бачення керівниитвом перспектив розвитку ринку $і$ свого підприємства зокрема. Запропоновано концептуальні підходи до впровадження бренд-менеджменту в управлінську діяльність підприємств, розглянуто приклади зарубіжного маркетингу. Ключові слова: бренд, бренд-менеджмент, концепція, стратегічний розвиток, споживач, модель, бренд-стратегія.
\end{abstract}

Создание и управление брендами явля ется залогом получения конкурентных преимуществ и долгосрочной рентабельности продуктов, услуг, компаний и организаций. Глубинные и научно обоснованные знания по маркетингу, инновациям и управлению брендами являются важными для каждого бизнеса и организации. Понимание поведения потребителя является основой для разработки стратегий бренд-менеджмента, а также оптимального позиционирования на рынке и эффрективной маркетинговой тактики. В статье рассматриваются проблемь определения задач бренд-менеджмента в контексте стратегического развития предприятия. Показано, что использование бренд-менеджмента является проявлением инновационной активности и стратегического видения руководством перспектив развития рынка и своего предприятия. Предложены концептуальные подходы к внедрению брендменеджмента в управленческую деятельность предприятий, рассмотрены примеры зарубежного маркетинга.

Ключевые слова: бренд, брендменеджмент, концепция, стратегическое развитие, потребитель, модель, брендстратегия.

Creating and managing brands is the key to gaining competitive advantage and long-term profitability for products, services, companies, and organizations. In-depth and evidence-based knowledge of marketing, consumer behavior, innovation, and brand management is important for every business and organization. Brand management is situational, episodic, and even controversial. Without the formation of a brand-oriented enterprise management system, it is not possible to ensure systematic brand management and accordingly a competitive position of the enterprise. There is a need for a mechanism that will allow to coordinate all the activities of the company in the direction of creating and strengthening the brand. Thus, as a brand is a strategic guideline for an enterprise, and not just a part of commodity or communication policy, it is a vital task to form a brand-oriented enterprise management. Branding that focuses on building lasting relationships with consumers is becoming a competitive tool. Understanding consumer behavior is the basis for developing brand management strategies as well as optimal market positioning and effective marketing tactics, especially when launching new goods market. The article deals with the problems of defining brand management tasks in the context of strategic enterprise development. It is shown that the use of brand management is a manifestation of innovative activity and strategic vision to guide the prospects of market development in general and its enterprise in particular. The content of the elements of brand management and its conceptual apparatus is substantiated, which ensures consistency in their interpretation. A brand management model has been built that contains a structural and logical scheme of management actions and reflects their cyclicality, which allows differentiating management processes. Conceptual approaches to introduction of brand management in the management activity of enterprises are offered, which allow to implement it depending on the degree of brand development, specificity of the company, readiness to use brand management in management activity, examples of foreign marketing are considered.

Key words: brand, brand management, concept, strategic development, consumer, model, brand strategy.

Постановка проблеми. Сучасні тенденції загальноекономічної стабілізації, насичення вітчизняних ринків товарами, посилення конкуренції, перспективи розвитку підприємств у системі господарських зв'язків, вихід українських економічних суб'єктів на світові ринки зумовлюють необхідність використання концептуально нових елементів управління стратегічним розвитком підприємства. За таких умов саме використання бренду та ефективної системи брендменеджменту сприятиме інноваціям у сорері виробництва та появі нових товарів. Однак процес упровадження бренд-менеджменту в управлінську діяльність відбувається доволі повільно, оскільки підприємства насамперед зосереджені на вирішенні проблем, пов'язаних з ефективним вико- ристанням матеріальних активів, а фрормування потенціалу стратегічного розвитку за рахунок бренду як нематеріального активу підприємства залишається поза їхньою увагою. Таке становище зумовлене певними проблемами соціальноекономічного характеру, відсутністю досвіду та недостатнім науково-методичним забезпеченням бренд-менеджменту з урахуванням особливостей ринкової економіки в Україні.

Аналіз останніх досліджень і публікацій. Нині, коли на світовому ринку пропозиція перевищує попит і поняття інновації стало майже ілюзією, важко створити щось нове, щоб привернути увагу вибагливого покупця. Слід відмітити і той факт, що вплив реклами сьогодні постійно зменшується, іноді неякісна рекламна кампанія може навіть 
принести збитки компанії, особливо коли йдеться про діяльність на закордонних ринках. I покупці досить легко переключаються з одного продукту на інший. Можна навіть спостерігати таку тенденцію: чим більше організацій конкурують на ринку, тим менше споживачі розрізняють їх, як наслідок цього - вимушена концентрація, злиття [1].

Аналіз останніх досліджень і публікацій свідчить, що в економічній літературі питанням брендменеджменту приділяється неабияка увага. Цьому питанню присвячені роботи таких відомих спеціалістів, як Ж.-Н. Капферер, Ф. Котлер, Ф. Гордон, М. Лекус, Д. Боуен, Р. Пріслоу, П. Дойль та інші. Проблеми, що пов'язані зі створенням успішних брендів, обговорюються у роботах Дж.К. Веркман, Г. Чармессона. 3 позиції поведінки споживачів бренди досліджуються у роботах Дж. Енджела, Р. Блекуелла та П. Мініарда [2].

Постановка завдання. Мета статті - дослідження сучасного концептуального підходу до системи бренд-менеджменту. Для досягнення поставленої мети необхідно: узагальнити теоретичні положення щодо сутності та призначення бренд-менеджменту в умовах ринкової економіки; дослідити сучасні науково-теоретичні підходи до формування бренд-менеджменту; оцінити ступінь його розвитку на підприємствах; розробити методичні рекомендації щодо впровадження брендменеджменту в управлінську діяльність підприємства для ефективного управління брендом.

Виклад основного матеріалу. Брендменеджмент - це діяльність, що ґрунтується на стратегічній орієнтації підприємства та має спрямованість на забезпечення прихильності споживачів, стійкості конкурентних позицій та довготривалого успіху підприємства [3]. Його метою $є$ розвиток та зростання вартості основного нематеріального активу підприємства - капіталу бренду. Тобто брендменеджмент на підприємстві виконує завдання забезпечення стійкого довгострокового попиту на продукцію; надання бренду додаткової цінності; формування стійкої бази для розширення бренду шляхом диференціації продукції; створення можливостей виходу на нові ринки і, в кінцевому результаті, підтримання відповідного рівня прибутковості.

Предметом бренд-менеджменту виступає система виробничих відносин, яка скеровує управління виробництвом на задоволення потреб споживачів за рахунок створення ланцюга «виробник - споживач», кожна ланка якого сприяє збільшенню цінностей для кінцевого споживача. Відповідно, об'єктами бренд-менеджменту є бренд, споживач та підприємство.

Основною метою фрормування стратегії розвитку бренду $є$ досягнення конкурентних переваг, тому стратегію розвитку бренду доцільно орормувати крізь призму основних стадій брендменеджменту як процесу управління [4].
На першому етапі визначається ставлення споживачів до бренду, що дає змогу встановити тип споживача, на який орієнтується бренд; а також фрормулюються критерії вибору, які властиві визначеному типу споживача; мотиви, якими керуються споживачі під час придбання бренду; інфрормація про погляди споживачів на конкуруючі бренди.

Другий етап передбачає визначення індивідуальних особливостей продукції, насамперед їі неповторності та унікальності, на рівні споживчих переваг. Третій - визначення потенціалу бренду 3 метою побудови його активу. Четвертий - це визначення ідентичності бренду, що дає змогу встановити напрям його розвитку. П'ятий етап вибір прийнятної бренд-стратегії, яку пропонуємо здійснювати за трьома критеріями відповідності: ринковому середовищу; ресурсам підприємства; споживчій аудиторії. Таким чином можна побудувати структурну схему управлінських дій, які відбуватимуться на вищенаведених етапах стратегії просування бренду.

Бренд - це образ, який існує у свідомості споживачів як реакція на товарний знак. Це обіцянка виробника за допомогою товару постійно надавати споживачу специфічний набір якостей, цінностей та послуг. Бренд - це сутність, що постійно розвивається у часі, від марки як концепції, яка складається з відомих елементів (фрірмової назви, фрірмового знаку, слогану), до чітко сприйнятої споживачами сукупності функціональних та емоційних елементів, що єдині 3 самим товаром та засобом його представлення. У цьому полягає головна відмінність бренду від товарного знаку, який являє собою позначення, які здатні відокремлювати відповідно товари та послуги одних юридичних та фрізичних осіб від однорідних товарів та послуг інших юридичних та фрізичних осіб. Далеко не кожна марка може стати брендом: для цього вона повинна стати відомою на ринку та завоювати довіру покупців. Можна виокремити такі етапи бренд-менеджменту:

1. Створення візуально-словесного вираження: фрірмова назва; товарний знак; фрірмовий стиль; слоган.

2. Використання у діяльності: ділових документах; рекламних заходах; рекламних сувенірах.

3. Формування бренду: рамки бренду; програма просування бренду; аналіз результатів програми.

4. Бренд, що вже створений та розвивається: дослідження; діагностика; програма подальшого розвитку.

Процес розвитку бренду має безперервний характер: навіть після того, як він починає самостійно працювати на ринку та приносити прибуток, необхідно здійснювати його оновлення, яке викликане змінами ринкового середовища та споживацького сприйняття [5].

Концепція брендингу виникла у межах північноамериканської школи маркетингу як практичний 
напрям. Вважається, що вперше система управління брендом була запропонована та використана у компанії Procter\&Gamble на початку 30-х pp. співробітником на ім'я Нік МакЕлрой, який був відповідальним за торгову марку мила «Camay» [6].

Можна сказати, що бренди та концепція управління ними з'явилися у той період, коли економічна система Заходу, що базується на принципах конкуренції, вже не могла без них обходитися. Їх використання стало єдиним засобом ідентифікації товарів за допомогою одного слова. Але поняття «брендинг» у розумінні його як маркетингової політики та фрілософрії фрірми увійшло у наш лексикон набагато пізніше. І, незважаючи на те, що розроблення концепції брендингу досить давно здійснюється багатьма зарубіжними дослідниками, єдиної та загальновизнаної думки стосовно цього питання немає.

У західній літературі є декілька видів брендів. Споріднені бренди - це бренди, які вміщують у себе як назву товарів, так і ім'я компанії-виробника. Наприклад, розробленням подібних брендів займається компанія «Nestle». Як один із різновидів споріднених брендів використовується «брендпарасолька». У цьому разі найчастіше наголошується на просуванні корпоративного бренду і закріпленні його у свідомості споживача як гарантії якості. У рекламі продукції фрірми демонструється її логотип, як, наприклад, реклама компанії «Danone».

У практиці маркетингу також є поняття «індивідуальний бренд». Індивідуальні бренди - це самостійні назви товару, які не містять навіть далекого натяку на компанію-виробника або країну походження. Наприклад, компанія «Procter\&Gamble», продукція якої виробляється під бренд-назвами «Ariel», «Tide» та ін., які абсолютно не пов'язані 3 назвою компанії. Деякі компанії називають брендами окремі товарні лінії. Наприклад, компанія «Jonson\&Jonson» продає під маркою «Jonson's Baby» серію дитячих гігієнічних товарів, а під маркою РН5.5 - лінію для догляду за волоссям і шкірою для дорослих.

Як бачимо, бренд у західному розумінні $є$ ключовим пунктом у міжнародній маркетинговій політиці фрірми. Аналізуючи вищезгадане, можна виділити такі стратегічні підходи до створення брендів у західній літературі:

- створення бренду, який містить у собі як назву продукції, так і назву виробника (споріднені бренди);

- створення індивідуального бренду, який передбачає самостійні назви товарів без будьякого натяку на фрірму-виробника (вони можуть по-різному позиціонуватися на ринку).

Але єдине, на що слід зробити наголос, це те, що у західній літературі бренд сприймається як особлива фрілософія бізнесу, як шлях досягнення успіху. Вищезгадані аспекти дають змогу розглядати бренд як складне та багатогранне поняття. Взаємодія на ринку споживача, товару та виробника формує основу для виникнення бренду як єдиного цілого. Ключовими елементами бренду $є$ торгова марка, бренд-імідж та брендинг. Їхнє головне завдання - створення значного марочного капіталу, тобто ринкового потенціалу бренду, який особливо важливий у довгостроковому аспекті [7].

Розглянемо «східний» підхід до створення брендів. В Азії прийнята дещо інша концепція корпоративний бренд. Фактично в Японії торгова марка товару без гарантії корпоративної марки не стала б купуватися. В Японії історично склалося, що після активного розвитку ринку у 50-60-ті роки, під час цінової конкуренції, покупці стали приділяти надмірну увагу якості товару. Але водночас іiї здатні забезпечити лише компанії-виробники, які мають достатній капітал для інвестування у наукові розробки. I тому західна система підходу до аналізу брендів споживачами, коли покупець навіть не знає, яка саме компанія виробляє товар, зовсім не узгоджувалася з японським менталітетом 60-х років, коли якість товару ототожнювалася з розміром самої компанії, її активами та капіталом. Саме тому у Японії склалася своя система рекламного та бренд-менеджменту. Наприклад, назва компаній «Sony» та «Panasonic», які вже зарекомендували себе як всесвітні лідери якості, стає «парасолькою» для назв «суббрендів» для товарних ліній (Sony Walkman - плеєри, Sony Trinitron - телевізори). Тобто в Японії первісно назва компанії (те, що стоїть за нею) є найголовнішою. Отже, основна цінність для японських компаній - високий корпоративний імідж, а не імідж окремих брендів [8].

Але світ не стоїть на місці. Економічне життя кожної країни розвивається настільки швидко, що майже неможливо говорити про якісь сталі тенденції. Тому в 90-х роках XX ст. відбулася інтеграція західного та східного підходів до брендменеджменту. Як ми можемо спостерігати, японські компанії почали впроваджувати систему вільних брендів (наприклад, компанія «Toyota» позиціонує абсолютно незалежно бренди «Тоyota»та «Lexus»). Але водночас європейські компанії, як, наприклад, «Philips», проводять рекламні кампанії своїх товарів лише під слоганами з корпоративним брендом «Philips - змінимо життя на краще».

Висновки 3 проведеного дослідження. На сучасному етапі бренд-менеджмент переходить у нову стадію - він стає основою діяльності організації і дає їй змогу опосередковано через управління брендом товару управляти ії̈ іміджем.

Формування стратегій управління брендом товару доцільно проводити у розрізі основних елементів: формування стратегій управління товарним портфелем підприємства; товарними 
марками товарів, що реалізує підприємство; ціновою політикою підприємства; методами збуту та засобами мерчандайзингу; сервісною підтримкою. 3 погляду на зазначені положення і висновки, підприємствам України слід спрямовувати зусилля бренд-менеджерів на розвиток комунікативних зв'язків, тобто на аналіз зовнішнього середовища та внутрішніх можливостей організації, що передбачає не лише спрямованість на ринок товарів і отримання прибутку, але й отримання зворотної інорормації для прийняття ефрективних управлінських рішень щодо виробничих процесів, фрінансових та маркетингових заходів, правового захисту бренду, стратегічних орієнтирів організації.

У кожній системі бренд-менеджменту $€$ свої позитивні та негативні риси, які фрірма повинна враховувати під час розроблення своєї стратегії. Серед переваг західної системи брендів слід виділити страхування від помилок: якщо на ринок вийде неякісний товар, це ніяк не позначиться на продажу інших брендів та іміджу компанії загалом. Але східний підхід роботи з брендами дозволяє компанії ефрективніше боротися 3 конкурентами і за допомогою корпоративного бренду виводити на ринок інші товари та послуги. Як свідчить практика, товарні та корпоративні бренди часто використовуються спільно, переносячи корпоративний імідж на продукт. У цьому разі корпоративні бренди найчастіше виступають як «парасолька», яка закриває весь товарний асортимент, тобто єдиний товарний знак, упаковка, фірмовий стиль, рекламний матеріал. Всі ці елементи робляться у єдиній емоційній стилістиці, що викликає у споживачів схожі або навіть однакові асоціації.

Отже, бренд-менеджмент - це пріоритетна фрункція усіх управлінців, а бренд-стратегія в межах системи бренд-менеджменту - це інвестиції в майбутнє організації.

\section{БІБЛІОГРАФІЧНИЙ СПИСОК:}

1. Свірідова С.С., Стойловська О.М. Проблеми стратегічного управління підприємством. Вісник Хмельницького університету. 2011. № 6. С. 290-292.

2. Завадяк P.І., Бойко Я.М., Гопак Н.М. Стан стратегічного управління на підприємствах 3 виробництва одягу. URL: http://dspace.uzhnu.edu.ua (дата звернення: 18.10.2019).

3. Гнатенко А.І., Поліщук Ю.А. Актуальні питання запровадження стратегічного підходу в менеджмент підприємств України. Теорія та практика державного управління. 2017. № 2(57). С. 1-7.

4. Данилюк В.О. Загальні проблеми стратегічного управління технічним розвитком підприємств України. URL: www.lib.nau.edu.ua (дата звернення: 18.10.2019)

5. Мокіна Ю.В., Кавуненко О.М. Проблеми стратегічного менеджменту великого та середнього бізнесу в Україні. Вісник Вінницького політехнічного інституту. 2013. № 3. С. 22-27.

6. Соколюк І.Р. Проблеми стратегічного управління на підприємствах України та шляхи їх вирішення. URL: $\quad$ http://wp.viem.edu.ua/konf7/art.php?id=0313 (дата звернення: 18.10.2019).

7. Мізюк Б.М. Особливості стратегічного управління підприємством. Фінанси України. 2012. № 12. С. 56-62.

\section{REFERENCES:}

1. Sviridova S.S., Stojlovsjka O.M. (2011) Problemy strateghichnogho upravlinnja pidpryjemstvom [Problems of strategic enterprise management]. Bulletin of Khmelnitsky University, no. 6, pp. 290-292.

2. Zavadjak R.I., Bojko Ja.M., Ghopak N.M. Stan strateghichnogho upravlinnja na pidpryjemstvakh z vyrobnyctva odjaghu [The state of strategic management in clothing production enterprises]. Available at: http://dspace. uzhnu.edu.ua (accessed 18 October 2019).

3. Ghnatenko A.I., Polishhuk Ju.A. (2017) Aktualjni pytannja zaprovadzhennja strateghichnogho pidkhodu $\checkmark$ menedzhment pidpryjemstv Ukrajiny [Topical issues of introducing a strategic approach to the management of Ukrainian enterprises]. Theory and practice of public administration, no. 2(57), pp. 1-7.

4. Danyljuk V.O. Zaghaljni problemy strateghichnogho upravlinnja tekhnichnym rozvytkom pidpryjemstv Ukrajiny [General problems of strategic management of technical development of Ukrainian enterprises]. Available at: www.lib.nau.edu.ua (accessed 18 October 2019).

5. Mokina Ju.V., Kavunenko O.M. (2013) Problemy strateghichnogho menedzhmentu velykogho ta serednjogho biznesu v Ukrajini [Problems of Strategic Management of Large and Medium Business in Ukraine] Bulletin of the Vinnitsa Polytechnic Institute, no. 3, pp. 22-27.

6. Sokoljuk I.R. Problemy strateghichnogho upravlinnja na pidpryjemstvakh Ukrajiny ta shljakhy jikh vyrishennja [Problems of strategic management at Ukrainian enterprises and ways of their solution]. Available at: http://wp.viem.edu.ua/konf7/art.php?id=0313 (accessed 18 October 2019).

7. Mizjuk B.M. (2012) Osoblyvosti strateghichnogho upravlinnja pidpryjemstvom [Features of strategic enterprise management]. Finance of Ukraine, no. 12, pp. 56-62. 
Martysh Yelyzaveta

Student

Kharkiv Academic-Scientific Institute

State Higher Educational Institution «University of Banking»

Hristoforova Elena

Candidate of Economic Sciences,

Senior Lecturer at Department of Management and Social and Humanitarian Sciences

Kharkiv Academic-Scientific Institute of the

State Higher Educational Institution «University of Banking»

Novikova Tatiana

Candidate of Economic Sciences, Senior Lecturer at Department of Management and Social and Humanitarian Sciences

Kharkiv Academic-Scientific Institute of the

State Higher Educational Institution «University of Banking»

\section{BRAND MANAGEMENT IN THE STRATEGIC ENTERPRISE MANAGEMENT SYSTEM}

The purpose of the article. The purpose of the article is to explore the modern conceptual approach to the brand management system. Modern tendencies of the general economic stabilization, saturation of domestic markets with goods, strengthening competition, prospects of development of enterprises in the system of economic ties, the exit of the Ukrainian economic entities in global markets require the use of conceptually new controls strategic enterprise development. In such circumstances, it is the use of the brand and an effective brand management system that will encourage innovation in the production and emergence of new products. However, the process of implementing branding in management is slow, since, first of all, focused on addressing issues related to the efficient use of tangible assets, and the formation of the potential of strategic development at the expense of the brand as an intangible asset of the enterprise remains out their attention. This situation is caused by certain problems of socio-economic nature, absence experience and insufficient scientific and methodological support of brand management, taking into account the peculiarities market economy in Ukraine.

Methodology. The purpose of the article is to explore the modern conceptual approach to the brand management system. Research methods In carrying out the work scientific methods of research: synthesis; induction; systematization and groupings; economic analysis; chronological methods; graphic representation method of results.

Results. At the present stage, brand management is moving into a new stage - it becomes the basis of the organization and allows it indirectly through the management of the brand product to manage its image.

It is advisable to carry out the formation of brand management strategies in the context of the basic elements: formation of strategies for managing the product portfolio of the enterprise; trademarks of goods sold by the enterprise; enterprise price policy; sales methods and merchandising tools; service support. In view of these provisions and conclusions, Ukrainian companies should focus their efforts on brand managers to develop communications, that is, to analyze the external environment and internal capabilities of the organization, which provides not only product market orientation and profit, but also feedback to make effective management decisions on production processes, financial and marketing activities, legal protection of the brand, strategic guidelines of the organization.

Each brand management system has its own positive and negative features that the firm should take into account when developing its strategy. One of the advantages of the Western branding system is the error insurance: if poor quality products enter the market, this will not affect the sales of other brands and the image of the company as a whole. But the oriental branding approach allows the company to compete more effectively with its competitors and, with the help of a corporate brand, to market other products and services. As evidenced by the practice, brand and corporate brands are often used together to transfer corporate image to the product. In this case, corporate brands often act as an "umbrella", which covers the entire product range, ie a single trademark, packaging, corporate identity, promotional material. All these elements are made in a single emotional style that causes similar or even similar associations among consumers.

Therefore, brand management is a priority function for all managers, and brand strategy within the brand management system is an investment in the future of the organization.

Practical implications. The introduction of a strategic approach in management at domestic enterprises will contribute to faster achievement of the set goals, increase of competitiveness and efficiency of activity.

Value/originality. To build a strong brand and be effective management should form an appropriate enterprise management system. An important task of such a management system is to orient the activities of all units enterprises to strengthen the brand position and increase its consumer value. Therefore, the question of forming a brand-oriented enterprise management system need further exploration and development. 